\title{
THE HEART OF THE MATTER: INTERPRETING BLOODSUCKING ACCUSATIONS IN MAURITANIA*
}

\author{
Erin Pettigrew \\ New York University Abu Dhabi
}

\begin{abstract}
This article examines events involving accusations of bloodsucking in the southwestern Sahara. French colonial archives allow researchers to identify specific cases in time and location; however, this article seeks to address but then move beyond histories of colonial governance. To highlight how communities in the Saharan desert dealt with crises provoked by environmental and social change, this investigation also relies on locally-produced written legal opinions and oral testimony. Emerging from these Saharan sources is one facet of how desert communities envisioned the enchantment of their social worlds and understood difficult periods caused by famine, weak economies, and domestic tensions.
\end{abstract}

\section{Key Words}

Sahara, West Africa, Mauritania, colonialism, race, slavery, gender, witchcraft, Islam.

In September I930, a resident administrator in the French colony of Mauritania noted a disturbing incident in his monthly political report. What the administrator considered an 'affair of little importance' in the town of Wādān necessitated minor disciplinary action on his part. ${ }^{\mathrm{I}}$ Here, in the summer heat accentuated by Wādān's rocky hillside, a woman of slave origin suffered torture and brutality at the hands of a local mob. Accused of 'being a witch and of having eaten the heart' of a woman from a prominent lineage, this 'female captive' was first attacked by 'overexcited young people' but then rescued by another inhabitant, Muhammad ould Bāba. ${ }^{2}$ The French administrator indicated that he

\footnotetext{
* Support for this research was provided by the Fulbright-Hays Research Fellowship, The American Institute of Maghrib Studies (AIMS), Stanford University, the Foreign Language and Area Studies Fellowship, and the Mellon Foundation. I thank Greg Mann, the anonymous reviewers of The Journal of African History, participants of the 'Dissections' Workshop at the CUNY Graduate Center and the AIMS Workshop held at Yale University, as well as Joel Beinin, Brandon County, Damien Droney, Mark Gardiner, Michael Gomez, Sean Hanretta, Christopher Hemmig, Marissa Mika, Uğur Peçe, Elly Power, Richard Roberts, Elias Saba, and Katherine Wiley for reading this article in its various forms. I also thank Yahya ould el-Bara, Ahmed Mahmoud ould Mohamed, and Sam Anderson for sharing documents and Ann McDougall, Benjamin Acloque, Mohamedou ould Meyine and Fatimatou mint ${ }^{\mathrm{c} A b d e l}$ Wahhab for continuing conversations over the longue durée of my research. Author's email: erin.pettigrew@nyu.edu

I Archives Provinciales de Chinguetti (APC), Dossier I930, 'Rapport politique du mois de septembre I930'.

2 Ibid.
} 
dealt with the matter by imposing a fine of Ioo francs and I 5 days in prison on the 'three guilty' parties. ${ }^{3}$

Whom the colonial resident understood as 'guilty' in this case is unclear. Likewise, the question of who reported the incident to the resident administrator only adds to the cryptic nature of this violence. In I930, Wādān was a minor oasis town of diminished commercial importance sitting on the edge of expansive dunes. The closest colonial official sat in Shinqìt, $90 \mathrm{~km}$ southwest over difficult terrain. Someone wanted the French officer to know about the troublesome events. Equally inaccessible through this short report are the actual circumstances and identities of the individuals implicated in this problem to be solved by a distant colonial administrator. In any event, the tensions had subsided by the time the officer knew about them. In the short description, the woman leveling the accusation of 'sorcery' against the captive does not seem to have died from having her heart consumed, leading one to assume that this extraction also meant something other than a physical removal of a vital organ. From the report, it seems Muhammad ould Bāba saved the accused from death and daily life returned to normal in Wādān. The report omits why such claims incited mob violence, how and why Muhammad ould Bāba effectively intervened, and what led to the dénouement of this local crisis.

Despite the details absent from this half-page report, this article opens with this incident to examine a kind of event involving accusations of 'extraction' (sellala) or the drawing out of vital bodily substances like the heart and, more commonly, blood, in the southwestern Sahara. The general patterns of accusation, violence, and reporting are repeated in other cases. Examining these cases and their contexts permits a consideration of crucial questions surrounding the kinds of anxiety troubling Saharan communities over the longer period of the nineteenth and twentieth centuries. While bloodsucking events in Mauritania do tend to follow certain patterns, the explanations given for this type of event vary considerably. Thus, in contrast to the cohesive analyses of bloodsucking and witchcraft produced by other Africanist scholars, this article suggests that the local meanings of bloodsucking in Mauritania were discordant in nature. ${ }^{4}$ Bloodsucking accusations and their related events are a primary perspective from which to view local conceptions of race and related fears about the significance of shifts in social hierarchy during the colonial period, old hostilities between lineages, as well as understandings of the nature of health and illness and their implications for social cohesion.

Researchers of Mauritania have already relied upon the colonial archive to identify bloodsucking events as reported to and dealt with by French officers. And, as in the Wādān case, they have remarked on a pattern of accusation that almost always finds slaves

3 Ibid.

4 See A. Ashforth, Witchcraft, Violence, and Democracy in South Africa (Chicago, 2005); J. Comaroff and J. L. Comaroff, 'Occult economies and the violence of abstraction: notes from the South African postcolony', American Ethnologist, 26:2 (1999), 279-303; C. Crais, The Politics of Evil: Magic, State Power, and the Political Imagination in South Africa (Cambridge, 2002); E. E. Evans-Pritchard, Witchcraft, Oracles and Magic among the Azande (Oxford, 1937); P. Geschiere, Sorcellerie et politique: la viande des autres (Paris, I995); R. Harms, River of Wealth, River of Sorrow: The Central Zaire Basin in the Era of the Slave and Ivory Trade, I500-I89I (New Haven, CT, I98I); and L. White, Speaking with Vampires: Rumor and History in Colonial Africa (Berkeley, 2000). 
or those of purported slave origin to be the target of such allegations. ${ }^{5}$ They have also used this archive to highlight social and administrative fears and poke at the limits of colonial governance when it came to the issue of slavery in Mauritania. ${ }^{6}$ In this territory where colonial governance was tenuous at best, French officers made a range of compromises with regional political and religious leaders in exchange for formal declarations of submission to French rule. ${ }^{7}$ This often required French officials' willful ignorance of the persistence of slavery and a promise to refrain from intervening in matters deemed 'Islamic'. Bloodsucking incidents in this Saharan region direct attention to both colonial tendencies as they tended to involve the enslaved (Ar. ${ }^{c} a b \bar{i}$, Fr. euphemisms captifs, serviteurs) or those considered free but whose slave origins were still recognized (brātīn) as well as the important factor of status accorded by race and religious knowledge to 'white' (bìdān), Arabophone scholarly groups. ${ }^{8}$

Local economic and political shifts in the first half of the twentieth century animated by cyclical droughts, the Second World War, and gradual movement away from slave labor greatly affected Saharan daily life, with colonial reports indicating that a phenomenon called 'bloodsucking' was perhaps one response to such changes in Mauritania. However, these administrative documents never take the accusations seriously and they rarely provide substantial information about the social dynamics at play in the incidents they describe. This article seeks to both address and also move beyond histories of colonial governance to highlight one way that Saharan communities dealt with local crises of environmental and social change. ${ }^{9}$ Although the colonial report on Wādān centered on claims of the female captive 'eating the heart' of another woman, eyewitness accounts are absent. Because physical and social distances separated colonial knowledge production about such

5 B. Acloque, 'Accusations of remote vampirism: the colonial administration in Mauritania investigates the execution of three slaves: I928-1929', in A. Bellagamba, S. Greene, and M. Klein (eds.), African Voices on Slavery and the Slave Trade (Cambridge, 2013), 282-304, esp. 286; E. A. McDougall, 'Slavery, sorcery and colonial "reality" in Mauritania, c. I9I0-I960', in C. Youé and T. Stapleton (eds.), Agency and Action in Colonial Africa: Essays for John E. Flint (Basingstoke, 200I), 69-82; P. Bonte, 'L'émirat de l'Adrar: histoire et anthropologie d'une société tribale du sahara occidental' (unpublished $\mathrm{PhD}$ thesis, École des hautes études en sciences sociales, I998), I729-33.

6 B. Acloque, 'Embarras de l'administration colonial: la question de l'esclavage au début du XXe siècle en Mauritanie', in M. Villasante-de Beauvais (ed.), Groupes serviles au Sahara: approche comparative à partir $d u$ cas des arabophones de Mauritanie (Paris, 2000), 97-I20; E. A. McDougall, 'A topsy-turvy world: slaves and freed slaves in the Mauritanian Adrar, I9I0-I950', in S. Miers and R. Roberts (eds.), The End of Slavery in Africa (Madison, WI, I988), 362-88.

7 See Archives Nationales de la République Islamique de la Mauritanie (ANRIM) EI/IO3, Soumission, années I904-I3.

8 For more on these terms and histories of race in the Sahara, see B. S. Hall, A History of Race in Muslim West Africa, I600-I960 (Cambridge, UK, 20I I); U. P. Ruf, Ending Slavery: Hierarchy, Dependency and Gender in Central Mauritania (Bielefeld, I999); and Villasante-de Beauvais (ed.), Groupes serviles au Sahara. Chouki El Hamel details the etymological debate over the term hrätīn between the Sanhaja Berber ahardan, indicating 'dark-colored', and the more commonly cited Arabic root hrrr. He translates it as 'free person of second class', writing that hrāțin refers to 'a group of people who occupied an intermediary position between slaves and free Muslims'. El Hamel, Black Morocco: A History of Slavery, Race, and Islam (Cambridge, UK, 2013), IO9-II.

9 See S. Feierman's analysis of how colonial documents veil the importance of unseen entities in 'Colonizers, scholars, and the creation of invisible histories', in V.E. Bonnell, L. A. Hunt, and R. Biernacki (eds.), Beyond the Cultural Turn: New Directions in the Study of Society (Berkeley, I999), I82-2 I6. 
events from local, Saharan epistemologies, relying solely on French reports provides only partial understanding. As such, moving outside of the framework of the colonial archive requires a turn to locally-produced Arabic texts and ethnographic interviews to access not only important details but especially ontological explanations of the events' meanings. From these Saharan sources, a fuller understanding emerges of how desert communities envisioned the forces of their social worlds during periods of famine, economic stagnation, and domestic tensions.

\section{PRECOLONIAL DESCRIPTIONS OF BLOODSUCKING}

By at least the late eighteenth century, some inhabitants of the southwestern Sahara were acquainted with bloodsucking episodes. As Yahya ould el-Bara noted in an essay on the political and religious context of reformist Sīdī cAbdullah ould al-Hājj Ibrahīm (d. I8I6/7), people were familiar with 'a kind of ability to harm people by focusing on them with sight and determination'. ${ }^{\text {Io }}$ To my knowledge, Ould al-Hājj Ibrahīm’s treatise, Rushd al-ghäfil (A guide for the lost), provides the earliest written documentation of bloodsucking in a formula for constructing a magic square (jadwal) to heal victims of selläl. ${ }^{\text {II }}$ Ould El-Bara explains that reciting the formula of letters in the square afforded protection from 'the kind of magic known as al-saghnīa or al-muṣs or al-sell'. ${ }^{22}$ Ould al-Hājj Ibrahīm had studied Islamic esoteric sciences to combat the effects of bloodsucking. ${ }^{{ }^{3}}$

In the historiography of Mauritania, scholars have explored how religious scholars in the Sahara deployed their knowledge of Islamic esoteric sciences as part of a claim to religious and moral authority. ${ }^{\mathrm{I}} 4$ Locally referred to as $l$ ' $h j \bar{a} b$, this secret wisdom of protective and healing sciences has been understood through the lens of Sufism and indicates a relationship to invisible spiritual entities (jnūn). In this 'Saharan Islamic culture', members of bìdān scholarly confederations garnered a mastery of these sciences through their learning of the Qur'àn. ${ }^{\text {I5 }}$ Claiming deep knowledge of the Islamic sciences also allowed them to function as intermediaries between various groups in the region because of their perceived exclusive ability to 'administer the invisible'. ${ }^{16}$ These Muslim experts were also often called

ıo Y. ould el-Bara, 'Al-fuqahā wa 'ulūm al-sirr wa al-shirr (al-murarif al-khaffiya)', unpublished article shared with permission by author.

I I See M. L. ould Muhammad al-Amīn al-Sālem, 'Awl baḥth ḥawl al-kitāba al-talismanīa fī morītāniā aw al-sirr al-hurf', Morìtānīa Akhbār, (https://goo.gl/tiıIAv), accessed ıо Apr. 20 I3.

I 2 Ould el-Bara, 'Al-fuqahā'.

I3 The Tagānt scholar studied with the Futa Jallon Fulani scholar Alfa Ibrahima who gave him this formula. Interviews with Husayn ould Mahand, Nouakchott, I7 July 20 I 2 and Hamden ould Tāh, Nouakchott, 20 Apr. 20I2. Bibliothèque Nationale de France (BNF), Richelieu, manuscrits orientaux, Arabe 685I, ff 284285 V. See also U. Rebstock, Maurische Literaturgeschichte, Volume III (Wurzberg, 200I), 7I 2.

I4 A. W. ould Cheikh, 'Nomadisme, islam et pouvoir politique dans la société maure précoloniale (XI siècle -XIX siècle): essai sur quelques aspects du tribalisme' (unpublished PhD thesis, Université de Paris V, I998), 90424; M. L. Nouhi, 'Religion and society in a Saharan tribal setting: authority and power in the zwāya religious culture' (unpublished PhD thesis, University of Alberta, 2009), I30-67, 295-303; L. Brenner, Controlling Knowledge: Religion, Power and Schooling in a West African Muslim Society (Bloomington, IN, $200 \mathrm{I}) ; \mathrm{B}$. F. Soares, Islam and the Prayer Economy: History and Authority in a Malian Town (Ann Arbor, MI, 2005).

I 5 E. A. McDougall, 'Snapshots from the Sahara: salt, the essence of being', in D. Mattingly et al. (eds.), Journal of Libyan Studies, 6: Special Issue (2006), 295-303.

I6 Ould Cheikh, 'Nomadisme', 922. 
upon to diagnose and treat the harmful effects of illicit magic, all of which ensured them a privileged role in socioeconomic and religious domains in the absence of an over-arching political authority for much of the region's history. ${ }^{\mathrm{I} 7}$

It is in the legal opinions (fatāwa) from one of the most renowned families of l'hjāb, the Azawād Kunta, where bloodsucking emerges again in textual form. An early nineteenthcentury legal opinion reveals that the phenomenon was well-established in the region when al-Shaykh Sīdī Muhammad bin al-Shaykh Sīdī al-Mukhtār al-Kuntī (d. I826), a respected descendent of the powerful Kunta Qāḍīīyya sufi and trading confederation, responded to a question about bloodsucking and its punishment. ${ }^{\mathrm{I} 8}$ The questioner asked if those 'who suck the blood from inside the body [are] to be killed', referencing the practice with the terms 'al-saghnīa called by most Arabs al-sellāla, what the Songhai call Karkara'. ${ }^{\text {I9 }}$ Al-Kuntī lived primarily among Touareg, Songhai, and Arab communities who knew bloodsucking by the Songhay term, karkara. The shaykh wrote about the karkaaw as a specific group of people who are known for 'bloodsucking from the veins inside the body until the drained person dies or nearly dies'. ${ }^{20}$

Al-Kuntī provided more details about bloodsucking in a second fatwā after he was asked about the kind of people who practice saghnia. ${ }^{21}$ He gave an example of those who suck their victims' blood, writing '[a]mong them is a group from India that kills people on the spot. They tear [open] the chest and do not find a heart there. They snatch it [the heart] from the chest with ambition and determination and psychological strength. ${ }^{22}$ In locating the origin of this practice in India, a land known as non-Muslim, al-Kuntī underscored its pre-Islamic and, thus, illegitimate foundation. He argued 'learning and teaching [sellāla], like all harmful magic, is to be a non-believer'. ${ }^{23}$ Classifying bloodsucking as an illicit sibr power meant that those who engaged in bloodsucking committed an act antithetical to Islam. Only a non-Muslim, a non-believer, would employ such methods.

I7 Ould Cheikh, 'Nomadisme'; Nouhi, 'Religion'; C. Hamès, 'l'Art talismanique en Islam d'Afrique occidentale: analyse anthropologique et islamologique d'un corpus de talismans à écriture' (unpublished $\mathrm{PhD}$ thesis, École Pratique des Hautes Études, I996-7), esp. 325-38; E. Pettigrew, 'Muslim healing, magic, and amulets in the twentieth-century history of the southern Sahara' (unpublished PhD thesis, Stanford University, 20I4).

I 8 The Kunta have been extensively studied for political and commercial dominance garnered through a monopoly over the Kedia Ijīl salt mine and their transmission of the Qādiriyya Sufi order. See Nouhi, 'Religion and society'; Y. ould El-Bara, 'The life of Shaykh Sīdī al-Mukhtar al-Kuntì', in S. Jeppie and S. Bachir Diagne (eds.), The Meanings of Timbuktu (Cape Town, 2008), I93-2II; and E. A. McDougall, 'The economics of Islam in the southern Sahara: the rise of the Kunta clan', Asian and African Studies, 20: I (I986), 45-60.

I9 Y. ould El-Bara, Al-majmuca al-kubrā: ahkām wa nuwāzil wa al-fatāwā al-shāmila ahl gharb wa janūb gharb al-șaḥara, Volume I2 (Nouakchott, 2010), Fatwā 6590, 6591. Recent online publications also use these terms interchangeably. See 'Al-sughnīa', Al-merkez al-cālmī li-drāsāt wa ābhạāth 'ulūm al-jānn, (http://www.jinnsc. com/vb/archive/index.php/t-I 2822.html), accessed I 5 Aug. 20 I6.

20 Ould el-Bara, Al-majmuca, Fatwā 6588, 6585. Perhaps a sign of a written error, in ould el-Bara's collection of published legal opinions, both karkara and karawa appear. See also Fatwā 6590, 659I.

2I This term can also be spelled with a $q$ (saqnia), but appears more in written texts across time than in contemporary interviews. The Soninké term used for bloodsucking is soukhounia.

22 Ould el-Bara, $A l$-majmuca, Fatwā 6588, 6585. These fatāwa indicate a connection in people's minds between bloodsucking and miscarriages. See Fatwā 6590, 6591.

23 Ould el-Bara, Al-majmuca, Fatwā $6588,6585$. 
He continued, explaining that evildoers 'practice this with a pomegranate by gathering from it the seeds until there are no longer any seeds left'. ${ }^{24}$ In both cases, the heart and the seeds had been removed from a distance, without lacerating the skin. This notion of an ability to remove the innermost body parts and liquids without actually touching the victim was a widespread aspect of bloodsucking accusations in Mauritania. The removal of essential life forces or organs occurred invisibly, so much so that the victims of sellala were often unaware that their heart or blood had been removed.

Three of the most prominent scholars of Mauritania have written about bloodsucking episodes, all relying on a shared corpus of colonial documentation and one locallyproduced but, in their cases, translated description of the phenomenon from the end of the nineteenth century. ${ }^{25}$ This last source, Sīdahmed ould al-Amīn's (dit al-Shinqīte, d. I9I3) 'The Encyclopedia of the biographies of the Literati of Shinqīt', better known as al-Wasit țas published in Cairo in I9 I I after al-Shinqīt left Mauritania I 5 years earlier. $^{26}$ The book describes the intellectual activity and traditions of al-Shinqīt?'s birthplace at the end of the nineteenth century, reflecting social life in the decades before the French colonial incursion. This was a time before the abolition of the regional slave trade and before colonial officials worked to monitor and shape local politics.

Writing for an audience unfamiliar with the cultural specificities of Mauritania, al-Shinqīt had an interest in portraying his native land as part of the Arab world instead of the 'Land of the blacks' (Bilād as-Sūdān), largely considered non-Muslim at the time. ${ }^{27}$ Al-Shinqīt included a short section in Al-Wasit entitled, 'Words on sorcery in Shinqiet'. Considerate of his audience, he used a term more broadly recognized in the Muslim world, siḅr, instead of the regionally-specific term sellala to describe an undated episode of bloodsucking accusations and fears in the date oasis town of Tijikja. Explaining that this 'sorcery' spread among the slaves in oasis communities, Al-Shinqit confirmed that an aggressor might attack by 'looking at the chest of a person' when he would 'pull out his heart, but he does not take it [the heart] except if he has contact with [the person] or with his shadow', emphasizing the malignant possibilities of a gaze. ${ }^{28}$

Encapsulating the central specificity of bloodsucking accusations in this contact zone between bì $\bar{a} n$ and 'black' populations, al-Shinqīte s's account reveals the crucial function of ideas about race, social hierarchy, and belonging in these incidents in Mauritania. In Al-Wasit's Tijikja case, this sorcery is portrayed as a slave's revenge for a master's

24 The North African scholar Ibn Khaldūn wrote a similar description five centuries earlier. Perhaps al-Kuntī drew from the former or both scholars relied upon earlier sources with explanatory goals in mind. Ould el-Bara, Al-majmuca; Ibn Khaldūn, The Muqaddimah: An Introduction to History, trans. F. Rosenthal (Princeton, 2005 [orig. pub. I967]), 394.

25 Acloque and McDougall incorrectly claim that the earliest written evidence appears in Sīdī Ahmed ibn Amīn al-Shinqīt’s Al-wasìt fi taräjim shinqìt wa kalām cala tilk al-bilād (Cairo, I9II) and that the phenomenon emerged later than Arabic texts indicate. Acloque, 'Accusations', 286 and McDougall 'Slavery', 70-6. Bonte does not hypothesize about the timing of sellāla's emergence but he only cites colonial mentions of 'sorcery'. See Bonte, 'L'émirat', I729 and I732. Ould Cheikh translated the text in 'Nomadisme', 43 I-2.

26 al-Shinqīt, Al-wasit.

27 See under the section heading (translated here) 'Words on Shinqīṭ: is it part of the Sūdān or of the Maghrib?', Ibid. 422 .

28 Ibid. 509. McDougall examines this case in 'Slavery'. 
mistreatment: 'If a master or anyone else hits a slave, he could be certain that 2 days later then his head will fall on a pillow and he will die suddenly and people say the slave is a sorcerer. ${ }^{29} \mathrm{He}$ wrote 'the reason for the existence of siḅr among the slaves of Shinqìt [present-day Mauritania] is that many of the slaves are imported from among the Bambara and they are black people and siḅr among them is beyond measure. ${ }^{30}$ Indeed, for al-Shinqìt and many of his bị̂an contemporaries, slaves were conceptualized as non-Muslim outsiders who came from a language and cultural group identified vaguely as 'Bambara'. ${ }^{\text {I }}$ The Saharan traveler must have also considered this kind of siḅr specific enough to his homeland to explain it to curious readers in the Middle East because other forms of sorcery and magic, such as the mixing of plant-based concoctions, animal and human hair and body parts, or formulae of incomprehensible incantations were also widespread and often classified under the same term, yet he only classified sellāla as 'sorcery'.

E. Ann McDougall has used this case to put forward two arguments about change over time when it came to bloodsucking. Firstly, she argues that the dominant bid $\bar{a} n$ community simply was not equipped to deal with this nefarious extraction, seeing it as something new to the region arriving with an influx of slaves at the end of the nineteenth century. ${ }^{32}$ She also claims that classifying bloodsucking as a consequence of the evil eye ( $\left.{ }^{c} a y n\right)$ is a sign of a narrowing of the distance between " "Moor" and "black" supernatural powers' as master and slave society blended. ${ }^{33}$ However, as shown above with antecedent Arabic documentation, bloodsucking was already widely known and dealt with by bì $\bar{a} n$ scholars much further into the Sahara. These earlier descriptions pointed to a determined stare being more frequent than physical touch when it came to the extraction of bodily organs or fluids.

In the Tijikja case, al-Shinqīt writes that the inhabitants of the oasis town discovered siḅr among their slaves and concluded they had to massacre all slaves to rid the town of this threat. Indeed, to proceed, the Tijikja inhabitants called for an expert from 'the land of the blacks' to undertake the task of cleansing the date oasis of its problematic slaves. ${ }^{34}$ Presumably, people in Tijikja trusted their invitee because he came from a region conceived

29 Ibid. Susan Rasmussen notes something similar among Nigerien Tuareg called 'bad work' in which people of slave origin kill from a distance. Rasmussen, 'Betrayal or affirmation? Transformations in witchcraft technologies of power, danger and agency among the Tuareg of Niger', in H. Moore and T. Sanders (eds.), Magical Interpretations, Material Realities: Modernity, Witchcraft and the Occult in Postcolonial Africa (London, 200I), I36-59, esp. I48.

30 Ibid. 509 .

3 I Until the 1905 decree banning the trade in slavery, most Saharan communities procured their slaves through war and trade with Wolof and Mandé-speaking neighbors. See Jean Bazin and his argument that 'Bambara appears in this [colonial and West African] world as the signifier for "the other"' and that 'in Senegal, all the captives coming from the interior were then called "Bambara"'. Bazin, 'A chacun son Bambara', in J.-L. Amselle and E. M'Bokolo (eds.), Au cour de l'ethnie: ethnies, tribalisme, et etat en Afrique (Paris, I985), 87-I25, esp. I05-6. Colonial officers noted Bambara and Malinké made up the majority of slaves. Archives Nationales du Sénégal (ANS) 2GI/96, 'Sénégal cercle de Kaédi, rapports trimestriels d'ensemble', I 898 .

32 McDougall, 'Slavery', 76.

33 Ibid. 76-7.

34 al-Shinqīt, Al-wasit, 509. 
of as akin to that of the slaves and had already successfully confronted sorcery in other communities. Once the slaves gathered, this paid specialist would 'give them curative drinks so they [would] vomit and the accused vomited what was known as siḅr. ${ }^{35}$ Although the specialist performed this procedure, taking his money and leaving, 'it was obvious that sibr remained in the slaves as before and people then killed whoever was a sorcerer. ${ }^{36}$ Al-Shinqit omitted how sorcerers were then distinguished from among the entirety of the slave population, but a further indication of the deep links in people's minds between slavery and sellāla is the fact that al-Shinqīt mentioned the towns of Tijikja, Ațār, and Awjeft as especially notorious for sellāla incidents. Busy date oases and caravan centers until the I940s, these Saharan communities were sites of slave labor and trade between sub-Saharan and North Africa.

Imagined as ritually powerful by bìdān, Bambara and other African slaves bore reputations as knowledgeable experts in the arts of herbal remedies and poison, in harmful magic, and flesh-eating. ${ }^{37}$ Often identified as non-Muslim or only marginally so even after converting, they allegedly practiced sciences forbidden by the Qur'ān and this illicit knowledge made them appear especially dangerous. Bì dân slave-reliant communities likely heard about or witnessed possession rituals and incidents of 'soul-eating' among neighboring black communities. ${ }^{38}$ Conceivably, bì $\bar{a} \bar{n}$ caravan traders and itinerant Muslim scholars could have carried observations and accounts of these practices back to their home communities. In the lower Senegal valley, people denounced as 'flesh-eaters' were sometimes sold to bi $\bar{d} \bar{a} n .{ }^{39}$ Slaves could have been purchased and voyaged with caravans further North into the desert carrying with them reputations as dangerous sorcerers. Slaves captured or sold as adults might have also carried rituals into bìdān-dominated oasis towns. Clearly, it was believable that slaves in oasis communities might wield their potent magic against local Muslim communities.

Al-Shinqīt explained that the motivations of slaves to strike out stemmed from 'the intensity of desire for meat, hunger and anger'.$^{\circ \circ}$ Meat and milk from camel, goat, and sometimes cow made up the foundation of desert diets in semi-nomadic and settled communities. Millet, dates, sugar, tea, and the rare vegetable grown in the colder months

35 Ibid.

36 Ibid.

37 In interviews, bì $\bar{a} n$ interlocutors recounted that bloodsucking was of Bambara origin. Interview with 'Abdarrahām ould Hanshī, Shinqīt, I Feb. 20I 2. For parallels, see Robin Derby's article, 'Haitians, magic, and money: raza and society in the Haitian-Dominican borderlands, I900-1937', Comparative Studies in Society and History, 36:3 (I994), 488-526 in which she explores how Dominicans imagine connections between Haitians and harmful magic.

38 Saint-Louis and Dakar fishing communities were known for ndö̈p, an event commemorating alliances with spirits. O. Ndoye, Le N’Dôep: transe thérapeutique chez les Lébous du Sénégal (Paris, 20Io). Wolof populations also referred to 'soul-eaters' (demm) and Halpulaar communities to 'people-eaters' (niamneddo). I. Sow, Divination Marabout Destin: aux sources de l'imaginaire (Dakar, 2009) and R. M. Dilley, Islamic and Caste Knowledge Practices among Haalpulaar'en in Senegal: Between Mosque and Termite Mound (Edinburgh, 2004), I40.

39 Acloque referencing Abbé David Boilat, in 'Accusations', 286; Boilat, Esquisses Sénégalaises (Paris, I984 [orig. pub. I 853 ]), 3 I6.

40 al-Shinqīt, Al-wasiț, 509. 
supplemented the usual Saharan fare. Both meat and milk, however, were scant in slave diets; therefore their nourishment of mostly seed grasses and grains left them prone to disease and higher mortality rates. ${ }^{4 \mathrm{I}}$ Bloodsucking was not only envisioned as malice toward individuals but also as a way for undernourished slaves to enrich their diets with victims' blood.

Over time, slaves were not always 'permanent strangers' in oasis towns, living among the dominant bì dān, converting to Islam, speaking Hassānīyya, bearing their masters' children, and breast-feeding the children of their mistresses. ${ }^{42}$ However, slave status not only carried the stigma of servility but it also meant restricted freedom when it came to movement, marriage, family, and economic independence. Opportunities differed based on gender because men were more likely to be manumitted by their masters, with possibilities of employment and movement often not afforded to women. In the minds of some bidàn, women of slave status might be especially covetous of their masters' marriages, kinship relations, or children if they were unable to similarly attain them. ${ }^{43}$

\section{ADMINISTRATIVE CONCERNS DURING THE COLONIAL PERIOD}

In 1905, two years after claiming Mauritania as a territory, the French administration abolished the purchase and use of slaves in its West African colonies. However, administrators willfully avoided enforcing this decree among Saharan nomads. ${ }^{44}$ Administrators on the ground observed how badly masters sometimes mistreated slaves; yet, colonial reports show officers were less likely to enforce anti-slavery laws in the northern and eastern areas where they barely established governing authority. ${ }^{45}$ Arguing that the policy only created instability, one officer observed in 1906 that ' $[t]$ his type of law would only provoke an uprising. Our occupation is too new and we should not forget that all the tribes, without exception, submitted to us on the clear condition that we respect their servants. ${ }^{46}$

When referring to problems involving slavery, officers used vocabulary designed to disguise its very existence. Instead of referencing a person's status as 'slave', they used the

4I J. L.A. Webb, Jr, Desert Frontier: Ecological and Economic Change along the Western Sahel, I600-I850 (Madison, WI, I995), 25, II9.

42 McDougall, 'Slavery', 77; Ruf, Ending Slavery, 98; Villasante-de Beauvais, 'La question des hierarchies sociales et des groupes serviles chez les Bidan', in Villasante-de Beauvais (ed.), Groupes Serviles au Sahara, 277-322, esp. 296. For slavery in West Africa, see M. A. Klein, 'The slave trade in the Western Sudan during the nineteenth century', Slavery and Abolition, I3:I (I992), 39-60; P. Lovejoy, Transformations in Slavery: A History of Slavery in Africa (Cambridge, UK, 2009); M. Rodet, Les migrantes ignorées du Haut-Sénégal, I900-I946 (Paris, 2009); and R. Roberts, Warriors, Merchants, and Slaves: The State and the Economy in the Middle Niger Valley, I700-1914 (Stanford, I987).

43 See traveler René Caillié's conversations with bìdān women concerned about relationships between husbands and women of slave status. Quoted in Ruf, Ending Slavery, IоI-2.

44 ANRIM Eı/6I, 'Esclavage', Mar. I906. For more, see Acloque, 'Embarras'; McDougall, 'Topsy-Turvy'; Ruf, Ending Slavery.

45 ANRIM Eı/47 n. 329, 'Rapport du Capitaine Duboi, Boutilimit, 8 mai I9I3, Cercle du Trārza, Correspondance divers', I9I2-I9I3; ANRIM EI/47 n. 329, 'Boutilimit le 3 Décembre', I920; ANRIM E2 n. Io, 'Atar le 2i Octobre', I9I0; APC I929 n. I40C, 'Note de service'; APC, 'Adrar', I938.

46 ANS 2G6/5, 'Mauritanie, rapports politiques trimestriels', I906. 
ambiguous terms 'captive', then 'servant'. ${ }^{47}$ Officers deliberately overlooked cases of mistreatment and abuse, preferring instead to preserve the tacit agreement between the ruling bid $\bar{a}$ n masters and the colonial government. Even as late as I939, Lieutenant Clairambault stated the informal policy on slavery was somewhere 'between the recognition of servants and effective abolition', describing the colonial position as 'tolerating without acknowledging' ${ }^{48}$

This everyday acceptance of slavery in its various persevering forms of unpaid labor and service by colonial administrators in Mauritania meant that the racialized and status-based nature of bloodsucking accusations had to be camouflaged. Mauritanians might conceal the identity of the accused to avoid calling attention to illegal labor practices or French officers masked the slave status of those accused of bloodsucking. If slavery could not be acknowledged in official correspondence, how could related tensions be addressed? Causal factors related to slavery in some of the cases of accusation and mob violence were ignored.

Despite the ambivalence of the colonial administrators who should have enforced the I905 laws, slaves did increasingly purchase, demand, or escape to freedom over the course of the colonial period. ${ }^{49}$ Manumitted men sometimes continued to work for their former masters but under new conditions. Men also had the ability to seek opportunities elsewhere, especially in the Senegal River Valley and on peanut plantations. ${ }^{50}$ Many women, however, remained in servile relationships. Responsible for their children, often with more intimate connections to their masters' families, women lacked the same options.

Besides a growing awareness of the abolition of slavery, two acute periods of famine during the colonial period seem to have most motivated slaves to leave their masters in the Adrār. In 1927, colonial officers remarked on the intensifying dryness in the region. The resident officer in Shinqịt observed in early March 1927 that the lack of rain meant there were no pastures for grazing animal herds. 'The tribes suffer from famine, to obtain the millet that they cannot find on the spot they send caravans in search of millet in Senegal and in the [French] Soudan.' ${ }^{1}$ Two weeks later, an officer in Ațār suggested sending for livestock from the southern Assaba region, hoping that I, Ioo sheep and Io cows could be transported north to his region. ${ }^{52}$ During the same drought cycle, an officer in Shinqìt noted rising tensions between inhabitants there as the date palms went barren, debts grew, theft became a problem, and slaves fled their dire conditions. ${ }^{53}$

47 An officer reminded that 'the word captive should not be used in official correspondence', exposing the intentional veiling of slavery in the colonial archive. ANRIM EI/77, 'Procès Verbal de Réunion du Conseil des Notables du Tagant, Séances des I3-I6 juillet I927, Tagant', I926-39.

48 Archives régionales d'Atar (ARA), I939 n. 44S, Lieutenant Clairambault, 'Rapport Annuel', I938; ANRIM EI/I 8, 'Esclavage', n. d. [no other information].

49 Bonte estimates the enslaved population of the Adrar made up 25 per cent of the population at the beginning of the twentieth century and $\mathrm{I}_{3}$ per cent at the end of the I950s. P. Bonte, L'émirat de l'Adrar mauritanien: harîm, compétition et protection dans une société tribale saharienne (Paris, 2008), I23.

50 O. Leservoisier, 'Les hrâtîn et le Fuuta Tooro, XIXème-XXème siècle: entre émancipation et dépendence', in Villasante-de Beauvais (ed.), Groupes serviles au Sahara, I47-67.

5 I ARA, Dossier I924, 'Objet: Dégrèvement zekkat moutons', 7 Mar. I927. See also ANS 2G27/I 7, 'Mauritanie rapport politique annuel', I927.

52 ARA, Dossier I924, 'Lieutenant Besson résident d'Atar à Monsieur le chef de bataillon commandant le cercle de l'Adar', 2I Mar. I924.

53 APC, Dossier I930. 
The I930s and early I940s were fraught with the effects of drought, famine, and a severe decline in the trans-Saharan caravan trade. ${ }^{54}$ From I939-44, Mauritanian populations suffered from the combined impact of a severe drought as well as agricultural restructuring aimed at supporting the war effort in Europe. During this terrible period, colonial officers reported that desert inhabitants strained to feed and clothe themselves. ${ }^{55}$ Earlier periods of drought led masters to sell their slaves, unable to feed them during a famine. ${ }^{56}$ A colonial report from the Adrār region observed that slave owners tried to 'get rid of their useless servants who [then] come fatten up the mass of miserable [people] and prostitutes', prostitution being one of the only paid jobs available to desperate women. ${ }^{57}$ Children ate trash to fill their bellies while their parents perished, and French administrators wrote about the Second World War's global economic consequences exacerbated in Mauritania by a lack of rain, transport, trade, and healthy livestock. ${ }^{58}$

Amidst these concerns, colonial documents barely reported on events or phenomena connected to bloodsucking, sorcery, or other invisible forces. Conceivably, Mauritanians understood that their colonial officers might not share a mutual appreciation for the dangers of bloodsucking, and they might have learned through experience to silence any betrayal of sellāla accusations and the accustomed consequent violence. When bloodsucking cases did appear, officers were dismissive of the accusations themselves. They more often focused on the resulting violence or tensions as a matter of administrative concern rather than extended anthropological inquiry. ${ }^{59}$

\section{PATTERNS AND CONTEXT}

Colonial archives do permit the identification of bloodsucking as a historical phenomenon and the little paperwork generated by these cases grants some analysis of general patterns during the colonial period. Yet, ethnographic conversation and oral history interviews allow for the kind of thick description necessary to begin understanding how, as Luise White argues, 'ordinary people recode and translate beliefs' ${ }^{60}$ I conducted formal and ad hoc interviews with Mauritanians from all regional, occupational, and lingual groups

54 In I930, a colonial officer worried about the 'sudden end of the caravan trade in camels and livestock to Senegal' and its effects on Adrār populations. APC Dossier I930, 'Rapports Politiques', Nov. I930. See also APC Dossier I93 I, 'Rapports Politiques', Jan. I93I; and ANS 9G3 I/I7, 'Famine', n. II3 and n. I90, I94I.

55 See ANS ${ }_{17} G_{553}$ I 5 n. 743 C, 'Chinguetti, Mauritanie, synthèses trimestrielles I943-I955' and n. 230C, 'Rapport du lieutenant colonel Schneider, 30 mars I943'; ANS 9G3I/I7 n. 85, II3, I90, I8; ANS I7GIo/I n. 24, 'Notes et renseignements, 30 Jan. I943'. Schneider noted that seventy people died due to faminerelated causes during a two-week period in Shinqịt.

56 Ruf, Ending Slavery, I 85; McDougall, 'Un monde', I3 I-2.

57 ANS ${ }_{17} G_{553} / I_{52}$, 'Chinguetti, Mauritanie, synthèse trimestrielle', I943-I955; n. 743C, 'Mise en valeur de l'Adrar', I943.

58 Ibid. n. $230 \mathrm{C}$.

59 Acloque, 'Accusations'. There are exceptions to this, see ANRIM EI/8, Cmdt. Busquet, 'Note sur la sorcellerie, Rapport Politique de la subdivision d'Atar', I936, and Pettigrew, 'Muslim', 206-77.

60 L. White, 'On unpacking the occult: why we need to go back to Friuli (or Transylvania for that matter)', University of Wisconsin, Madison, (http://z3.invisionfree.com/Free_Thinkers_II/ar/t542.htm), accessed I4 Aug. 2016. 
of the country. Sometimes, our conversations were public with other family members or neighbors listening. More often, and especially with people whose social status might prevent them from speaking forcefully in public, I talked with individuals alone. Over time, I noticed a repeated pattern in the ways interlocutors discussed bloodsucking, situating the phenomenon within the moral and religious landscape of Saharan life. I use this received model, of locating bloodsucking within an Islamic framework before moving on to contextualize the initial Wādān case.

In the Arabophone southwestern Sahara, local explanations of extraordinary exsanguination rely on two related terms that this article glosses as 'bloodsucking': a verb meaning 'to extract' or 'draw out' (sell) and a noun phrase meaning 'the sucking of blood' (imtiṣạs al-demm). ${ }^{6 \mathrm{I}}$ In oral history interviews conducted in the Adrār region where Wādān is situated (2OII-I6), interlocutors most frequently spoke of 'extraction' (sellāla) to describe this drawing of blood from someone's body. ${ }^{62}$ Among local conceptions of good and evil, sellāla falls under the rubric of those practices condemned in the Qur'ān for their methods as well as their goal of harming others through opaque techniques. These particular actions of consuming bodily fluids and organs are especially condemned because drinking blood and eating carrion are explicitly prohibited in Islamic dietary law. ${ }^{63}$ Saharans not only saw blood as a vital fluid that ensured physical health, but they also understood that the red liquid made up the human soul. ${ }^{64}$ Bloodsucking was then denounced as a category of 'sorcery' and 'black magic' (siḥr and hikma al-kahla), both clearly forbidden in Islam. ${ }^{65}$

Contemporary oral testimony places bloodsucking under the umbrella of 'the evil eye' ('ayn); although, as noted earlier, the gaze was always an important aspect of early descriptions of bloodsucking. ${ }^{66}$ As with the evil eye, the assailant fixes a person with his/her eyes, staring at the victim's chest and unleashing the destructive consequences of jealousy. Explanatory examples include infertile or unmarried women envying a married mother or that of men of weak social standing coveting another's power. A person with destructive designs might try to learn sellāla techniques from a knowledgeable expert but, more often, bloodsucking expertise was understood as inherited from mother to child through birth or breast milk. ${ }^{67}$ Other stories warned children not to drink or eat anything from someone

6I Of note, al-sell in Arabic means 'tuberculosis'; however, local ethnographic and written sources do not draw connections between bloodsucking and tuberculosis. Al-Shinqīt listed tuberculosis among other common maladies such as worms and conjunctivitis in 'Words on Illness and Health in Shinqit', yet he clearly understood tuberculosis as a lung problem cured by curdled milk. al-Shinqīt, ANRIM EI/8507-9.

62 In interviews, these terms were almost interchangeable with the second term (imtiṣa ạ al-demm) shortened to 'the act of sucking' (al-mușs).

63 Qur'ān, 2, I73.

64 Awfa quoted in Paul Dubié, “"El 'Omda”: poème sur la médicine maure', trans. M. ould Ebnou Aden in Bulletin de l'IFAN, 5:5 (I943), 38-66, esp. 44.

65 Among the most cited verses are Qur'ān: 20:66, 7:II6, 2:IO2, II3, and II4. Today, ḥikma al-kaḥla is often used with a dual meaning of 'black' in mind, indicating the dark arts but also people identified as racially 'black'.

66 Interview with 'Abdel Azīz ould Fata 'Ama, Nouakchott, I 5 May 20 I 2; interview with Shaykh Amadu Bamba ould Sayār, Tigumāṭin, I9 Jan. 20I2; interview with Moulay Aḥmed ould Moulay Zāyn, Shinqīṭ, I9 Mar. 2012.

$67^{\mathrm{c} A b d e l}$ Azīz ould Fata cAma and interview with Muhammad Ould Zāmel, Nouakchott, 9 July 20 2 . For more on milk and its symbolic and generative role in Mauritania, see C. Fortier, 'Le lait, le sperme, le dos. Et le sang? 
identified as a sellāl because ingesting something he or she prepared might lead to sickness or death. ${ }^{68}$ Descendents of known aggressors were feared and marginalized based on the presumption that they inherited this harmful potential.

An ethnographic interview in Shinqīt featured a townswoman demonstrating to regional Muslim figures how she exercised her sinister powers. Instead of the exotic pomegranate, she used a date palm - a typical plant of oasis agriculture - to illustrate how sellāla worked in the Sahara:

This was during the date harvest season and she pointed to some date palms that were far from where they were standing, pointing out that some were red and some were yellow. She looked at the dates and the dates were suddenly in her clothes, in her veil. That's how she sucks the blood of people. She sucked the dates or was able to magically take one off the far-off trees. She said that that's the way she uses sell. ${ }^{69}$

Pulling ripe dates off a distant tree and, then still without moving, producing them in the folds of a veil points to a recurring aspect of what Acloque has termed 'remote vampirism' ${ }^{70}$ Another oral account tells of how a woman outside of Shinqit once held the end of a string, telling her victim to sit across from her with the other end. When the woman began twisting the string over and over again, blood dripped down the center, falling to the sand underneath. The blood trickled from an invisible wound, terrifying the victim. ${ }^{7 \mathrm{I}}$ While the selläla, or bloodsucker, never physically touched her victim, the string was pulled taut between them, allowing her to slowly draw out the woman's blood to collect and seep down the fiber.

If the process of removing bodily fluids and organs occurred imperceptibly, the symptoms of sellala were more visible. Drained of blood, the skin turned pale and the victim might have fluttered in and out of consciousness. Writing from the regional capital of Ațār, an interested French administrator penned 'Notes on Sorcery' in I936 after his region struggled with a series of the consequences of bloodsucking accusations and subsequent violence. $^{72}$ Commandant Busquet was situated between the towns of Shinqit and Wādān, as well as the palm oases of Awjevt and M'hereith. The latter two oases were especially notorious for their high incidences of sellāla. Busquet observed of bloodsucking incidents in the Adrār that 'the sick person practically cannot make even the smallest movement: he is "like dead"; he mumbles in a sort of delirium'. Pallid, the victim no longer had any blood under his skin, so much so that 'Moors say that one could even cut the skin or even a vein or an artery of such a sick person; no blood would come out. They say that

Représentations physiologiques de la filiation et de la parenté de lait en islam malékite et dans la société maure de Mauritanie', Cahier d'études africaines (hereafter CEA), I:I6I (200I), 97-I38.

68 Of course, many slaves or women of slave origin served as wet nurses and prepared food for their masters or employers. Interview with Sen̄i ould cAbdāwa, Nouakchott, 28 July 20I2. For recent descriptions of bloodsucking, see M. M. ould Aḥmed Sīdī ould Sīdī Yahya, Al-mujtemac al-fadfād: mṣlaḥizāt sūsīūlogia hawl al-mrā' wa al-șulța wa al-thaqāfa fī al-mujtmac al-mürītānī al-mcuāṣr (Nouakchott, 2002), I03-5; and A. ould Moḥammed ould Hamīn min Al Barikallah al-Faḍilī, Al-wasūl wa al-tarsīkh bimunāqib al-shāykh elì al-shāykh: hādì al-rijāl ila ḥadira dhī al-jilāl (Nouakchott, n. d.), I89-92.

69 Author's fieldnotes and interview with Abba ould Aḥmed Mạ̣mūd, Shinqūt, 22 Mar. 20 I 2.

70 Acloque, 'Accusations'.

7I Interview with 'Ayshetū mint Samorī, Shinqīṭ, 2 July $20{ }_{3}$.

72 Busquet, 'Note sur la sorcellerie'. 
these witches [feminine] ... drink the blood or eat the heart of their victims. ${ }^{73}$ Those who fell prey to bloodsucking were left near death in the Sahara where their family members found them. A decade later Lieutenant François Beslay, serving in Shinqīt from I945-7, reported on the 'beliefs and para-religious precepts in Mauritania'. ${ }^{74} \mathrm{He}$ explained that 'the Moors claim there are a number of people gifted with a magical power who kill their victims from a distance by drinking the blood (usell) ... Shinqìt is a place reputed as full of people (particularly black [people]) with this power., ${ }^{75}$

Narrowing down the causal factor in the invalid's case necessitated the expertise of a Muslim spiritual mediator ( $h a j a \bar{b})$ to examine the sick person's body and aliments. ${ }^{76}$ Fading in and out of consciousness, the sick person would release 'only inarticulate sounds where one can discover the name of the witch [feminine], when he saw her, [when she] looked at him'.77 Accused bloodsuckers rarely confessed the crime, but they nevertheless remained objects of suspicion and intense energy focused upon eliminating the threat of illness and/or death caused by bloodsucking. At its worst, this anger could erupt into violence, as happened in the I930 case from Wādān. Regarded as 'sorcerers' (sāḥira), those convicted of bloodsucking were therefore to be punished with death. Their bodies were often dragged out of town and abandoned in the desert without a proper Muslim funeral. ${ }^{78}$

Colonial reports of bloodsucking incidents in Mauritania, like the episode in Al-Wasit, point to the clustering of such episodes in oasis towns. Awjeft, east of Ațār, appears most prominently in these reports. Once a thriving date oasis and stop for caravans trading in slaves and salt, Awjeft and the neighboring villages of Tungād and M'hereith relied primarily on slave labor to harvest dates and seasonal agriculture. ${ }^{79}$ These three Saharan communities were known for a high incidence of sellala and for the presence of spirits in their environs. One elderly interlocutor from Awjeft condemned the frequent mob attacks in his village, suggesting that there were other, more sanctioned options for suturing the social wounds caused by bloodsucking accusations. He described this aggressive process of accusation and violence as 'brutal', saying 'it was against the shari'a what they were doing before. ... People would accuse, then just torture, beat, and kill. ${ }^{8 \circ}$

As with the examples from the Kunta fatāwa, people desperate for help could approach a Muslim cleric for a legal opinion on the matter at hand and on how best to cope with illness caused by bloodsucking. Nonetheless, angry crowds usually rejected the objections of religious leaders. As a cleric in Shinqịt noted when explaining a colonial-era case of a woman killing her slave:

73 Ibid.

74 Archives Nationales Pierrefitte-sur-Seine (ANPS), Centre des Hautes Etudes sur l'Afrique et l'Asie Moderne (CHEAM), 20000002/37 I003, Lt François Beslay, 'Croyances et préceptes parareligieux en Mauritanie', Thesis, No. 1003, 1946.

75 Ibid. 8.

76 See Pettigrew, 'Muslim' for more on spiritual mediators.

77 Busquet, 'Notes sur la sorcellerie'.

78 Interview with Muhammad ould Bahan, Shinqịt, I May 20 I 2.

79 Interview with Muhammad 'Abdellahī ould Aḥmed 'Abdī, Awjeft, I4 July 20 I 2.

$80 \mathrm{Ibid}$. 
Before colonization, everyone engaged in these practices. Slaves were killed. Those who owned slaves had the right to do this. Slaves were like animals at that time. When that [bloodsucking accusations] happened, people did not go see the Muslim clerics. The slave did not have a family so no one pressed charges. ${ }^{, 81}$

Importantly, the frequent pleas of these respected male elders indicate that bloodsucking accusations were not universally accepted as credible or that these men advocated an alternative process for mediating the situation. Those convinced that bloodsucking had in fact occurred avoided the formal spaces of resolution (a colonial administrative office or a Muslim cleric's room) since each venue's authorities might have prevented the type of trial and brutal punishment desired by incensed mobs. ${ }^{82}$ Because these cases concluded in moments of hostility, news of the events reached French officers who were then obliged to consider intervention in this disturbance of social order. The return to calm, the loss of a family member or servant, and the psychological relief of the families whose members were now safe from future attacks are absent in the colonial narratives of these events.

In interviews, local historians and elders tended to explain bloodsucking accusations as a way of rationalizing illness caused by anemia, diabetes, malaria, or high blood pressure. With any of these illnesses, a person might faint, feel weak, and appear pale afterward. For others, it was actually the restricted meat consumption among poorly-fed slaves, or later brāțin, that drove someone to suck another person's blood. One elderly hajāb in Awjeft recounted how a woman from his town once sucked people's blood, mixing it with camel hair and turning it into a bloody string with which she magically fabricated a goat to eat. ${ }^{8}$ In a region where meat was both an expensive yet vital part of the desert diet, these ties between red meat and bloodsucking stories seemed especially evocative of the challenges of life in the Sahara.

Interviewees who questioned the truth of sellāla accusations leaned toward jealousy playing a large role in such events where accusations were linked to fears about social reproduction in Saharan communities. ${ }^{84}$ Bi $\bar{d} \bar{a} n$ women leveled this accusation against certain women slaves, thus making sure that their husbands would remain faithful to the marriage and preserve the social status afforded by bì $\bar{a} n$ genealogy. With a labor economy depending largely on slave and hrțanīa women as domestic servants, bīân women harbored legitimate anxieties about their husbands striking up relationships with these women. The low status granted to slaves and hrtanīa made women especially vulnerable to accusations of sellāla, which could be leveled to socially isolate and exclude women threatening to destabilize the family.

While the earlier Arabic sources do not point to gender as a noticeable factor in bloodsucking episodes, some colonial reports and the bulk of my conversations with Mauritanians indicate that women were more likely suspected of this crime. By and large, accounts and explanations from both sets of sources point to women, especially

8I Interview with Abba ould Aḥmed Mahmmūd. This is supported by Acloque, 'Accusations'.

82 In Islamic jurisprudence ( $f$ iqh), one should avoid calling for criminal sanctions if there are any ambiguities in a case. The invisibility of hard evidence would make a trial that tested cases of bloodsucking difficult if carried out following fiqh principles of evidence.

83 Interview with ould Ahmed 'Abdī.

84 Interview with Senī ould cAbdāwa, Awjeft, I3 July 20 I 2. 
those of slave status or servile origin, as attackers. While there were and continue to be narratives of men of slave origin as well as people belonging to the low-ranking occupational groups of the tributary znega and iron-working mucallimin identified with bloodsucking, 'black' women were overwhelmingly the predominant victims of these accusations. ${ }^{85}$ When I asked present-day hrātinn interlocutors how they understood motivations behind bloodsucking accusations, their responses linked to race, arguing that such charges were almost always blamed on those considered 'black' and of slave descent. ${ }^{86}$ In some interviews, bloodsucking accusations were directed at the weakest members: people with mental illness, unmarried women, and alienated ḅțani $^{-87}$

In this case, these explanations, not unlike histories of witchcraft accusation in medieval Europe and later New England, are connected to anxieties about the place of marginalized women in society. Carol Karlsen writes that ' $[\mathrm{t}]$ he story of witchcraft is primarily the story of women ... witchcraft confronts us with ideas about women, with fears about women, with the place of women in society, and with women themselves. ${ }^{88}$ A prominent antislavery activist understood the selläla charges against an elderly slave woman in his hometown as stemming from her owner's envy after she achieved economic independence and purchased a home. ${ }^{89}$ 'We accuse the most intelligent people of sell', he stated, explaining that the owner's family members, having used the allegations to isolate the woman from her social milieu, were then able to claim the woman's property.

In a West African context, Andrew Apter has shown that the anti-witch Atinga movement in I950s Yorubaland should be analyzed 'as a drama which sought to comprehend and control' structural change as a growing cocoa economy created new opportunities for women and junior men to bypass patriarchal authority. ${ }^{\circ 0}$ In Mauritania and despite the absence of a booming economy, slaves and hrātin progressively felt emboldened to leave and act independently from their masters. Others joined religious groups considered heterodox, meeting autonomously and promoting new forms of religious practice and piety. ${ }^{9 \mathrm{I}}$ Conceivably, a master class worried about shifts in the landscape of labor and social authority could have deployed an already-existing idiom, that of bloodsucking, against those threatening to destabilize gender and religious norms. One hrțania woman in Awjeft interpreted bloodsucking as a way for local Muslim spiritual mediators to earn money by diagnosing bloodsucking as a cause of illness or a means of taking revenge

85 Recent jokes and stories about bloodsucking include examples of accusations against the iron-working/artisan occupational group suspected of Jewish origins.

86 Interview with Amenitū mint Swaydi Muhammad, Awjeft, I 4 July 20I 2; interview with Boubacar Messacūd, Nouakchott, 5 Aug. 20I 2; interview with Tidjanī ould Ramaḍān ould Sacid, Ațār, 3 July, 20I3. See Pettigrew for a I960s example in which a bìdān Sufi figure manumitted two slave women accused of bloodsucking: 'Muslim', 263-7I.

87 Interview with Tidjanī ould Ramaḍān ould Sacid.

88 C. F. Karlsen, The Devil in the Shape of a Woman: Witchcraft in Colonial New England (New York, I998), xii, I 17 .

89 Interview with Boubacar Messacūd.

90 A. Apter, 'Atinga revisited: Yoruba witchcraft and the cocoa economy, I950-5I', in J. Comaroff and J. Comaroff (eds.), Modernity and its Malcontents: Ritual and Power in Postcolonial Africa (Chicago, I993), I I I-28, esp. I20-I.

9I On I960 and I970s Awjeft, see Pettigrew, 'Muslim', 263-7I. 
on someone through a public allegation..$^{92}$ If this is partly true, and in light of increasing, yet still inadequate, access to biomedical care, these spiritual mediators might have insisted upon bloodsucking as a cause of misfortune in order to preserve their own roles in local communities. ${ }^{93}$ Experts in the religious sciences were the only people capable of overcoming the evil manifested through bloodsucking.

\section{CONCLUSION}

The events in Wādān occurred in September I930 during what should have been the height of the rainy season, providing a harvest of dates and their rich source of calories. However, in November I930, an officer observed that it was already 'a bad year' filled with 'deprivation and misery'. ${ }^{94}$ Locusts swarmed into the Adrār, devouring the already limited agriculture. ${ }^{95}$ As one Shinqīt elder recalled, this period of famine was nicknamed the infertile times' (zemān tenwaka) indicating a period when date palms were dying and not producing harvests as usual. ${ }^{96}$ Indeed when Muhammad Lemīn ould Sadfa ould Bābā evoked his grandfather's role in the episode, starvation played a crucial part in explaining the local crisis. ${ }^{97}$ Yet, the official report of the Wādān sellāla episode did not allude to the persisting famine playing any role in events described. Furthermore, Wādān had long been divided politically by two dominant tribes: the Idaw al-Hājj and the Kunta. ${ }^{98}$ The schism is important because, according to the colonial report and to Muhammad ould Bābā's grandson, two of the bidann women centrally involved in the bloodsucking case came from these two leading tribes. After a hajāb diagnosed bloodsucking as the cause of illness in the victim - the Kunta bid $\bar{a} n$ woman - the culprit was identified as the slave of a bi $\bar{d} \bar{a} n$ woman from the Idaw al-Hājj. Townspeople took the slave to the center of town. They put her on an erected cross and beat her with sticks until 'she cried and people said that if she wanted them to stop, she had to give back the woman's blood'. ${ }^{99}$ Here entered Muhammad ould Bābā, an Idaw al-Hājj notable from Wādān, to argue against this torture and the basis for accusing the slave of bloodsucking. Claiming that the accuser, the Kunta woman, was full of lies, he gave her three glasses of goat's blood which made her vomit up the little that was in her stomach - some measly date pits. ${ }^{\text {Ioo }}$ As explained by Muhammad

\footnotetext{
92 Interview with Amenitū mint Swaydi Muhammad.

93 Elderly Awjeft ḥajāb ould Aḥmed cAbdī lamented that no one sought his healing expertise anymore. Interview, see fn. 79.

94 APC, Dossier I930, 'Rapports politiques', Nov. I930.

95 ANS 9G67/I07 (previously 9G28/I7), 3 Nov. I930, Bulletin de Renseignements and ANS 2G30/3, n. 33, 'Rapport sur la situation politique de la Mauritanie', Année I930, Mauritanie, Rapport politique annuel.

96 Interview with ould Aḥmed Mahmūd.

97 Interview with Muhammad Lemīn ould Sadfa ould Bābā, Nouakchott, 6 July 20 I 2.

98 J. L.A. Webb, 'The evolution of the Idaw al-Hajj commercial diaspora', CEA, I3 8-9:(XXXV-2-3) (I995), 455-75 and G. Lydon, On Trans-Saharan Trails: Islamic Law, Trade Networks, and Cross-Cultural Exchange in Nineteenth-Century Western Africa (Cambridge, 2009), 82.

99 Interview with ould Sadfa ould Bābā. While the colonial report indicated the alleged victim's heart was 'eaten', the oral interview relied on terminology for bloodsucking.

Ioo Ibid. Colonial reports during times of food shortage note that populations ate date pits and grasshoppers, indicating that both were otherwise not a usual part of the local diet. 'Now, date pits are entering the diet. The natives smash them raw and make couscous with it or grill them to drink with sugar and dates
} 
ould Bābā's grandson, the hollowness of the wealthy woman's stomach revealed just how much she was feigning her own wellbeing. Instead of appealing to others for more nourishing food, this woman 'lied' and filled her stomach with date pits to satiate her hunger. ${ }^{\text {Ior }}$

Muhammad ould Bābā pointed at the dates and said to the surrounding crowd, instead of accusing this poor woman [the slave], feed this woman [the Kunta woman]'. ${ }^{\text {IO2 }}$ Arguing that the townspeople would do better to care for each other, rather than attack a defenseless slave of an elderly woman, Muḥammad ould Bābā's moralizing argument prevented further violence. As ould Bābā's grandson perceptively explained, the social positioning of the two noble women mattered, for 'only people without strong masters' could be accused of sellāla, for 'a hajāb would never say that someone from a powerful family was sellāla' ${ }^{\text {IO3 }}$ As the ould Bābā family remembered the incident, the weak social status of the Idaw al-Hājj mistress as well as the persisting competition between the town's dominant tribes left her slave vulnerable to accusation.

The multilayered nature of these bloodsucking events points to how these accusations were contingent upon a diverse set of historical and social factors. The case from Wādān underlines some of the central ambiguities of sellāla and its local meanings. We know that the case involved women from the two prominent tribes in the town, tribes that happened to have long-term tensions related to commerce, religious authority, and political control. We know that the events occurred during a period of famine when inhabitants resorted to eating date pits in order to satiate their starvation and that this detail was used to stop the violence against a woman of slave status. We know that the French officer in Shinqị somehow heard about the events and felt a need to superficially respond and report on the violence. What we do not know is exactly why the hungry Kunta woman accused her neighbor's slave of bloodsucking nor how the town dealt with the consequences of public torture and violence. It is likely that Muhammad ould Bābā intervened on behalf of the slave's mistress, a woman from his own tribe, however we do not know the specificity of his motivations. We do not know who informed the colonial administration of these events and why. Never clarified, we also do not know whom the French resident identified as the 'guilty' parties in this case, though it is doubtful they were ever actually fined or arrested as suggested in the archival document.

In the precarious environment of the Sahara desert, blood was seen as a coveted, lifesustaining commodity for the hungry and socially marginalized. As early as the late eighteenth century, bloodsucking appeared in locally-produced legal texts of prominent Sufi experts in the esoteric sciences of healing and protection. In towns with substantial slave populations, bid $\bar{a} n$ feared their slave residents as non-Muslim and thus ritually-powerful, ravenous, and jealous. The idiom of bloodsucking was the same and was mobilized as a tool of social alienation and cause for murder. During periods of drought and in the context of longer local tensions between trading confederations, the accusation was leveled against the weakest members of a community. In the twentieth century, as some hrāținn

like coffee.' People in Atār 'fe[d] themselves with the heart of adult palm trees'. APC, 'Bulletins de renseignements subdivision de Chinguetti', Jan. I94 I.

IOI Interview with ould Sadfa ould Bābā.

IO2 Ibid.

IO3 Ibid. 
and former slaves accumulated capital and sought economic and educational opportunities, sellāla was a kind of idiom used to preserve the old social order. The specific contexts of each incident reveal how a range of forces such as colonialism, the end of slavery, or famine played out locally through tribal tensions, an ill child, or domestic intimacy and jealousy. The reasons for mobilizing this idiom might vary over time and according to context; however, a remarkable consistency points to the same people accused of this crime. Overwhelmingly uttered by bị $\bar{d} \bar{n}$ and often by bìd $\bar{a} n$ slave owners against black inhabitants of desert communities, sellāla thus emerged as an accusation demarcating and preserving racial and social difference. 